\title{
UMA FIGURA DE PADRE COMO TEMA LITERÁRIO: O PADRE ANTÓNIO VIEIRA NA FICÇÃO LITERÁRIA DO BRASIL
}

\author{
José Eduardo Franco* \\ Universidade de Lisboa - ULisboa \\ joseeduardofranco@gmail.com \\ Vanda Figueiredo** \\ Universidade do Minho - UMinho \\ v.santosfigueiredo@gmail.com
}

RESUMO: Considerando a literatura do ponto de vista da receção e da recriação de personagens históricas, analisaremos a presença da figura do padre António Vieira na ficção literária do Brasil. Para isso, debruçar-nos-emos sobre as obras "Mariana Pinta", de Firmino Rodrigues da Silva, Manuel de Moraes - Crónica do Século XVII, de João Manuel Pereira da Silva, e Boca do Inferno, de Ana Miranda, com o propósito de mostrarmos de que modo António Vieira é (re)construído, a partir de dados e elementos biográficos, como personagem ficcional.

PALAVRAS-CHAVE: personagens históricas - recriação - Padre António Vieira - ficção literária brasileira

\section{THE FIGURE OF A PRIEST AS A LITERARY THEME:}

* Doutorado pela École des Hautes Études en Sciences Sociales de Paris em História e Civilização e Doutorado em Cultura pela Universidade de Aveiro. Professor em Centro de Literaturas de Expressão Portuguesa das Universidades de Lisboa. Coordena actualmente um vasto projecto de pesquisa, levantamento e edição dos Documentos sobre a História da Expansão Portuguesa existentes no Arquivo Secreto do Vaticano financiado pela Fundação para a Ciência e a Tecnologia e promovido pelo Centro de Estudos de Povos e Culturas de Expressão Portuguesa da Universidade Católica Portuguesa.

** Tem uma Licenciatura em Ensino de Português (2008) e uma pós-graduação em Teoria da Literatura (Ramo de Literaturas Lusófonas) (2009) pela Universidade do Minho. Atualmente, é investigadora de doutoramento do Centro de Estudos Humanísticos da Universidade do Minho (CEHUM), sendo bolseira da Fundação para a Ciência e Tecnologia (FCT). Tem experiência na área de Letras, com ênfase em Língua e Literatura Portuguesas. 


\title{
FATHER ANTÓNIO VIEIRA IN THE LITERARY FICTION OF BRAZIL
}

\begin{abstract}
Considering literature from the perspective of reception and recreation of historical figures, we will analyse the presence of the figure of Father António Vieira in the literary fiction of Brazil. In doing so, we will focus on the "Mariana Pinta" works by Firmino Rodrigues da Silva, Manuel de Moraes - Crónica do Século XVII, by João Manuel Pereira da Silva, and Boca do Inferno, by Ana Miranda, in order to show how António Vieira is (re)constructed, based on biographical data, as a fictional character.
\end{abstract}

KEYWORDS: historical characters - recreation - Father António Vieira - Brazilian literary fiction.

A literatura é um jogo combinatório que explora as possibilidades implícitas no seu próprio material, independente da personalidade do poeta, mas é um jogo que em certa altura se reveste de um significado

inesperado, um significado que não está patente no plano linguístico (...), mas que se introduziu a partir de outro nível, ativando algo que nesse segundo nível é muito importante para o autor e para a sociedade em que ele vive. Italo Calvino

O campo da criação literária é fecundo no processo de cristalização de imagens do passado, não só em termos avaliativos, mas também ao nível da evidenciação de perspetivas de compreensão. Neste sentido, a receção literária de figuras ${ }^{1}$ e de acontecimentos históricos parece-nos bastante relevante para o estudo da forma como o passado é reconstruído.

Nos textos literários, através do poder da linguagem artística, as figuras históricas tornam-se personagens, surgindo com uma nova vida e novas características, não só com um propósito estético, mas também com fins ideológicos e doutrinários, ou com uma intenção pedagógica de rememoração. Efetivamente, de acordo com José Augusto Mourão, “a literatura tem por função essencial fazer memória, testemunhas,

1 Sobre os conceitos de figura, pessoa e figuração, veja-se este estudo de Carlos Reis: Figura, pessoa, figuração. In Colóquio/Letras, No 199, setembro/dezembro de 2018, p. 9-29. 


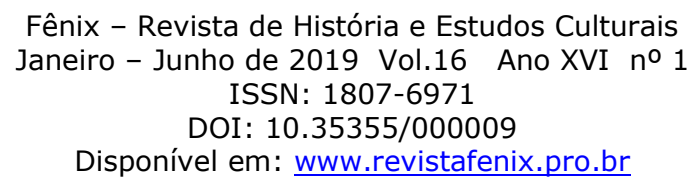

criar mundos, falar daquilo que não se pode dizer", sendo "o melhor testemunho, o mais vasto espaço da memória e o melhor remédio para o esquecimento".2

A literatura constitui-se, portanto, como um exercício imaginativo de reconstrução, por vezes de reconstrução transfiguradora, e de instauração de significados. Vejamos, a propósito, o que refere Manuel Antunes:

(...) uma obra literária é um mito. Isto é: uma palavra que revela e oculta; uma palavra do passado que se atualiza no presente; uma imagem da vida e uma transfiguração da mesma vida; um símbolo que reúne, num espaço comum, coisas distantes e opostas; uma alegoria que sobrenada as águas profundas da afectividade, percorre a existência e desemboca num horizonte onde se perde deixando de ser funcional. Uma obra literária é um mito mas é também, pela sua mesma realidade de objecto sui generis, um constructo. Queremos dizer: não a cópia de uma cópia, mas um opus que é fruto da imaginação antecipadora do poeta, da capacidade, que o habita, de negar o passado, ao mesmo tempo que se sente possuído por ele, e da racionalidade planificadora. ${ }^{3}$

Dizendo de outro modo: a ficção literária resulta da ação da imaginação sobre os materiais reais em que se inspira, configurados e reconfigurados em função de um ideal. Daí que, no exercício hermenêutico das obras, o jontexto epocal e as circunstâncias individuais dos autores permitam, por vezes, tornar translúcidas palavras e frases, extraindo-lhes os sentidos segundos, maquilhados pela sua natureza conotativa. $^{4}$

Voltando um pouco atrás, importa notar o facto de determinadas ações e personalidades históricas surgirem com mais frequência no universo da ficção literária. É o caso de António Vieira, personagem recorrente em muitos textos brasileiros e portugueses $^{5}$ (como o é também, aliás, na pintura, no cinema ou na música) ${ }^{6}$, criada e

2 FRANCO, José Eduardo. (Coord.). Obra Seleta de José Augusto Mourão. O Vento e o Fogo. A Palavra e o Sopro. O Espelho e o Eco. Lisboa: Imprensa Nacional-Casa da Moeda, 2017. 1592 p., p. 354. Veja-se também CALVINO, Italo. Punto y aparte. s/l: Tusquets, 1995. 360 p., p. 354.

3 COELHO, Eduardo Prado; REAL, Miguel. (Coord.). Obra Completa do Padre Manuel Antunes. Lisboa: Fundação Calouste Gulbenkian, 2009. 614 p., Tomo V, Volume I, p. 49.

4 De facto, importa considerar aquilo a que podemos chamar a "ideologia" do autor, ou seja, a sua mundividência, decorrente das suas convicções profundas. Cf. ISER, Wolfgang. The Range of Interpretation. New York: Columbia University Press, 2000. 280 p., p. 14.

5 Além dos textos que serão aqui analisados, podemos, a título ilustrativo, referir as seguintes obras: Um ano na Corte (1850), de João Andrade Corvo; A Máscara Vermelha (1873) e O Juramento da Duquesa (1873), de Pinheiro Chagas; O drama e a Glória de Padre António Vieira (1952), de 


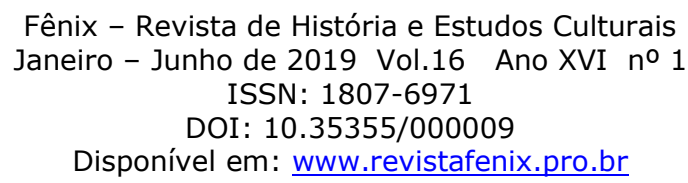

recriada por autores como Machado de Assis ou Nélida Piñon, Fernando Pessoa ou José Saramago. ${ }^{7}$ Com efeito, o percurso biográfico e a originalidade do pensamento precursor do padre António Vieira, na sua vida longa que atravessa todas as décadas do tormentoso século XVII, tornam-no uma personagem sugestiva e inspiradora. ${ }^{8}$

Além disso, a representação de Vieira em obras literárias deve-se, em grande parte, à relevância que a figura do padre, na sua relação privilegiada com a Igreja Católica, vai assumindo a partir do século XIX. De facto, cumpre-nos notar que a temática religiosa tem sido, até aos dias de hoje, frequentemente tratada na literatura, a qual, como sabemos, busca no sagrado motivos e mistérios potenciadores da energia imaginária de que vive. ${ }^{9}$ Assim, as narrativas sagradas, nomeadamente as que

Mário Domingues; António Vieira. O fogo e a Rosa (2008), de Seomara da Veiga Ferreira; O Sal da Terra (2008), de Miguel Real.

6 Neste âmbito, podemos lembrar o filme que Manoel Oliveira leva à tela no ano 2000, com o título Palavra e utopia. Sobre António Vieira no cinema, veja-se a tese de doutoramento de Francisco Jiménez Caldeirón, subordinada ao tema Imagem e Discurso: Os textos de António Vieira e a Linguagem Cinematográfica, apresentada em 2010, na Faculdade de Filosofia e Letras da Universidade da Extremadura (Cáceres - Espanha).

7 Uma personagem histórica que, criada literariamente, se torna personagem extraordinária, como explica Lídia Jorge: "Se não se tratasse de um abuso de linguagem, eu diria que as personagens são da natureza da metafísica, por serem inapreensíveis, evanescentes e ao mesmo tempo duráveis para sempre. As personagens permanecem dentro dos livros sob a forma de fantasmas pacíficos que se movem no meio do papel (...). Avatares de nenhuma divindade externa, só têm existência quando os leitores abrem as páginas e levantam de entre as linhas impressas os ossos e a carne dos seus corpos, e a aura dos seus espíritos. (...) As bibliotecas encerram humanidades inteiras, adormecidas, à espera de voltarem a viver pela leitura. (....) Mas há outras personagens às quais cabe a sorte de passarem a um outro tipo de suporte e a um outro género e vida além da sua vida de papel. Personagens que deixam o seu lugar silencioso de limbo semiobscurecido, onde só brilham pelo efeito da poção mágica da imaginação do leitor, para se tornarem mais próximas das pessoas reais, e nesse caso dá-se um salto de iluminação extraordinária". JORGE, Lídia. Personagens e a sua sobrevida. In Colóquio/Letras, $\mathrm{N}^{\circ}$ 199, setembro/dezembro de 2018, p. 78 (pp. 79-79).

8 Aliás, a grandeza de Vieira equipara-se à de outras figuras que o seu século dá, como poucos, à humanidade, como escreve Anne-Laure Angoulvent: “(...) a grande força do barroco reside numa concentração notável de grandes espíritos. O princípio do século XVII é, sem dúvida, o último grande momento da história individual da humanidade em que os mesmos homens compreendem e apreendem todas as grandes disciplinas. Com efeito, eles podem, se não dominar todos os conhecimentos, pelo menos compreender-lhes o funcionamento. Um autor pode, ao mesmo tempo, dominar, através do conhecimento do grego, do latim, do pensamento judaico e pelo que pode conhecer do pensamento árabe, as línguas que são veiculares do pensamento ocidental (com algumas influências árabes). Este mesmo autor possui, portanto, os instrumentos linguísticos de apreensão das estruturas interpretativas do homem e do universo". ANGOULVENT, Anne-Laure. O Barroco. Lisboa: Publicações Europa-América, 1996. 234 p., p. 12.

9 Como bem analisa Manuel Antunes num dos seus ensaios de crítica literária: "O tema do santo e o tema do padre são frequentes na literatura de hoje. Juntos ou dissociados, invadiram o teatro e o romance, as duas formas mais adequadas para tratar, existencialmente, os problemas mais transcendentes e, até, os mais abstractos. A partir, sobretudo, do célebre Le Journal d'un Curé de Campagne de Bernanos, publicado há perto de vinte anos, uma vasta literatura, em quase todas as latitudes do mundo ocidental, tem gravitado à volta do padre e do santo. Apenas alguns títulos: The 


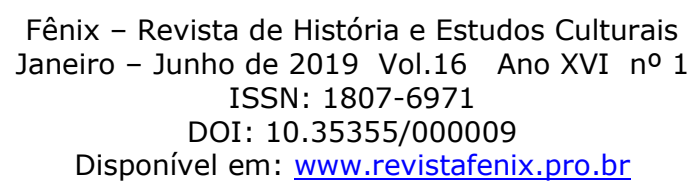

descrevem as "histórias míticas" fundadoras do mundo e da humanidade, bem como das suas derivas dramáticas no tempo, acabam, em boa medida, por se constituir como matriz dos enredos romanescos da literatura secularizada. Daí que um dos mais emblemáticos livros sagrados e modeladores da cultura ocidental, a Bíblia, esteja na base de estruturas narrativas desenvolvidas fora do ambiente religioso. É, pois, no contexto das relações entre estes dois campos de criação, um sagrado, outro profano, que deve perceber-se a emergência de figuras religiosas tornadas personagens literárias, como o padre, o santo ou o anjo e, mais concretamente, o padre António Vieira.

Antes de nos debruçarmos sobre os textos literários em análise, é necessário salientar os mais importantes traços da biografia de Vieira e, por outro lado, problematizar o processo complexo das perceções e da leitura da sua ação religiosa e política, na medida em que este pregador do barroco luso-brasileiro se torna um paradoxo interpretativo, marcado, na sua receção, por um conflito de interpretações que se estende desde o seu tempo até ao século XX. ${ }^{10} \mathrm{Na}$ verdade, Vieira simboliza aquela que é, em grande medida, a perceção antropológica da cultura barroca enquanto paradoxo.

Power and Glory de G. Greene (O Poder e a Glória, na trad. portuguesa); The Cardinal do americano Henry Morton Robinson; La Dernière à l'Échafaud (na trad. francesa) da escritora alemã Gertrud Von Le Fort, livro de onde Bernanos extraiu a sua última mensagem, Dialogue des Carmelites; Les Saints vont en Enfer de Gilbert Cesbron (Os Santos vão para o Inferno, na trad. portuguesa); Sur la Terre comme au Ciel (trad. francesa), drama do austríaco F. Hochwalder; Léon Morin, Prêtre de Béatrix Beck; O Céu e a Terra do italiano Carlo Coccioli (...). Um duplo aspecto - convergente ou divergente - solicita, com respeito ao sacerdote, a atenção dos escritores e leitores de hoje: o homem de Deus e o homem dos homens; o homem de Deus ou o homem dos homens. Por outras palavras: trata-se de saber se o padre há-de traduzir, vitalmente traduzir, uma espiritualidade de escatologia e encarnação ou se há de acentuar - por vezes, quase até à eliminação do outro - um dos dois termos. (...) Não apenas pelo gosto do mágico e do extraordinário que sempre vive no coração do homem e irrompe, quase fatalmente, nos momentos de crise; não apenas pela ânsia de desvendar o mistério desses seres à parte, espaços vivos onde os extremos - o Céu e a Terra, Deus e o Diabo - se encontram e combatem mais encarniçadamente; mas também, na derrocada dos valores humanos, desaparecidos em catástrofes colectivas ou apanhados na mecanização geral da existência, o padre e o santo, sendo portadores do Espírito e da Vida, dão a seus irmãos um pouco de esperança. De facto, só o santo nos pode consolar da imensa tristeza que invadiu o mundo, da miséria de ser homem, hoje." COELHO, Eduardo Prado; REAL, Miguel. (Coord.). Obra Completa do Padre do Padre Manuel Antunes. Lisboa: Fundação Calouste Gulbenkian, 2009. 614 p., Tomo V, Volume I, pp. 36-37.

De algum modo, António Vieira, em algumas das obras literárias em que é retratado, resume um conjunto de expectativas, ideários e combates que têm como pano de fundo, mais do que a figura do sacerdote, a figura do herói e do santo ou do profeta, do denunciador dos males que afetam os homens e a sociedade do seu tempo.

10 Sobre a teoria da receção neste sentido, veja-se PALMER, Richard E. Hermenêutica. Lisboa: Edições 70, 2006. 288 p., p. 20; e RICOEUR, Paul. Teoria da Interpretação. Lisboa: Edições 70, 2009. 136p. 
No concernente aos aspetos biográficos, António Vieira nasce em Portugal, na cidade de Lisboa, mas parte cedo para a Baía, formando-se no Colégio dos Jesuítas daquela então capital das Terras de Vera Cruz, como padre da Companhia de Jesus. Passa mais de metade da sua vida no Brasil, onde atua como professor, missionário, líder de expedições missionárias e de redes de construção de aldeamentos destinados a evangelizar e a educar os ameríndios. Outra parte da sua carreira, que lhe dá muita notoriedade, fá-la na corte portuguesa, como pregador real, conselheiro régio e diplomata extraordinário na Europa, ao serviço do rei D. João IV, no quadro do esforço diplomático para obter o reconhecimento da restauração da independência portuguesa frente a Espanha, a partir da década de 40 do século XVII. Por conseguinte, alterna e complementa o seu trabalho religioso com o cumprimento de funções políticas.

Viaja diversas vezes entre o velho continente europeu e o chamado Novo Mundo, experimentando, como poucos, vivências em situações extremas e extremamente opostas. Tanto calcorreia os corredores dos palácios mais luxuosos das cortes europeias, como vive entre os ameríndios, na selva amazónica, em condições inóspitas para um europeu não nascido em meio selvagem. ${ }^{11}$ Convive e estabelece amizades quer com os indígenas brasileiros, quer com membros das altas elites europeias e dos mais diversos setores da sociedade, como reis, rainhas, príncipes, princesas, padres, bispos, navegadores, governadores, comerciantes e corsários.

Considerado genial pelos seus admiradores e amigos, que o apreciam com quase devoção, o caráter fogoso e frontalmente denunciador de Vieira, relativamente às injustiças e ao que exige necessidade de reforma e de melhoramento social e político, valem-lhe a multiplicação de inimigos que o incomodam seriamente, pondo em causa a sua vida. Em suma: Vieira é uma das figuras da cultura portuguesa que, em virtude da força, do significado e do choque crítico das suas ideias e da sua ação, provoca correntes de leitura divergentes e mesmo antagónicas, nas quais apenas coincide o reconhecimento do seu talento: para uns uma bênção, para outros um "génio demoníaco", rebelde e perigoso.

Se os admiradores de Vieira se empenham em publicar e em divulgar os seus escritos, defendendo a sua boa fama, os adversários desenvolvem uma corrente que tem

11 Cf. FRANCO, José Eduardo (Coord.). Entre a Selva e a Corte: Novos Olhares Sobre Vieira. Lisboa: Esfera do Caos, 2009. 264 p. 
o seu apogeu no tempo do Marquês de Pombal e durante o antijesuítico século XIX. Este movimento pode ser designado por antivieirismo, quer pela sua dimensão polémica e de produção de imagens negativas, quer pelo tom doutrinário da avaliação de António Vieira, porque enquadrada numa apreciação negativa associada aos jesuítas no seu todo.

O antivieirismo começa por manifestar-se na tentativa de limitar a ação de Vieira e na condenação do seu pensamento sobre o presente e o futuro de Portugal na relação com a sua teologia da história de matriz cristã. Já na segunda metade do século XVII, correspondente à fase em que alcança notoriedade como pregador ao serviço do rei D. João IV, emerge um antivieirismo físico e político, que evolui para um antivieirismo teológico-religioso. E é também notório o antivieirismo interno à própria Companhia de Jesus, revelado na crítica de alguns confrades à sua atuação e ao seu ideário políticos, crítica materializada, desde logo, na primeira denúncia à Inquisição, em 1649. No que respeita concretamente à Inquisição, adversária maior de Vieira, destacam-se ainda os julgamentos de membros de outras ordens religiosas e, inclusivamente, o de Soror Joana da Cruz, que, do México, condena uma tese teológica evidente no sermão vieriano do Mandato sobre as finezas de Nosso Senhor.

O século XVIII fica marcado pela crítica iluminista à Companhia de Jesus, que resulta na sua extinção e na expulsão dos seus membros. Para isso, Pombal tem um papel fundamental, instituindo aquela que se torna a matriz do movimento antijesuítico. Vieira tem um lugar de destaque na propaganda antijesuítica pombalina, desde logo na obra que podemos considerar como a bíblia do antijesuitismo, a Dedução Cronológica e Analítica, bem como no compêndio documental em sete volumes organizado a mando do primeiro-ministro de Dom José I, com o título bem sugestivo de Maquinações de Vieira Jesuita. ${ }^{12}$ Neste âmbito, Vieira é considerado um génio maquinador, ao serviço da ordem religiosa inaciana e contra os interesses de Portugal e da Igreja. Note-se que esta imagem é consagrada pelo antivieirismo ulterior, ainda que com ligeiras diferenças.

12 Cf. "Maquinações de António Vieira Jesuíta", Biblioteca Nacional de Portugal (Lisboa), Secção de reservados, códs. 2673-2679. Estes compêndios de fontes não contêm qualquer introdução aos documentos reunidos. Nos seus sete volumes, manuscritos em letra clara de fácil leitura, encontramos um acervo constituído por cartas, relatórios, sermões, petições, entre outros. Estes documentos são da autoria de Vieira ou a ele endereçados. Encontra-se também uma cópia destas "Maquinações" na Biblioteca Nacional do Rio de Janeiro, na Divisão de manuscritos, cód. I-12,02, 021. 


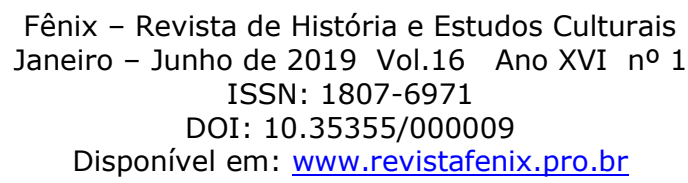

Durante um longo período, os juízos sobre Vieira são, portanto, marcados por leituras em chave dicotómica e de tom maniqueísta. ${ }^{13}$ Assim, ainda na segunda metade do século XIX, enquanto autores laicos e antijesuítas desconsideram o pregador e as elucubrações barrocas dos seus sermões, como Teófilo Braga, pelo contrário, Oliveira Martins expressa a sua admiração pelo jesuíta (admiração, aliás, partilhada por muitos), designadamente ao defini-lo enquanto "homem superior que está à frente do moderno Portugal, como o guia, o mestre, o fundador; multiforme na capacidade, omnímodo na ação missionária e diplomática, financeira e estadista e, por isso, filósofo, moralista e literato". ${ }^{14}$

Ora, a receção literária de Vieira, representado como personagem de enredos e intrigas, assume uma dimensão importante para aferir a perceção da vida e obra deste autor, assim como para perceber as diferentes apreciações a que é sujeito ao longo dos séculos. De facto, a literatura é a pátria da criação, mas também da avaliação das grandezas e baixezas das ações humanas e da elevação moral dos seus protagonistas. Não significa que a avaliação seja sempre justa, mas sedimenta, muitas vezes, a vox temporum estabilizadora de um juízo sobre o legado de alguém, a partir da sua influência transformadora em diferentes domínios, ou tendo em conta a pertinência das suas ideias e intervenções para os coetâneos e, mais ainda, para os vindouros.

É precisamente neste sentido que analisamos as obras selecionadas: "Mariana Pinta”, de Firmino Rodrigues da Silva (1838), Manuel de Moraes - Crónica do Século

13 Todavia, hoje em dia, o jesuíta é considerado, quase unanimemente, como uma das figuras maiores da história literária, política e religiosa de Portugal e do Brasil. Como escritor, pensador e homem de ação, tem tido, nos últimos 50 anos, uma grande valorização e um enorme reconhecimento em vários meios de saber universitário, nomeadamente de alguns países com comunidades de estudiosos da língua e da cultura portuguesas, destacando-se Itália, França, Alemanha, Espanha, Holanda, Estados Unidos da América e México.

No coro dos seus admiradores, contam-se figuras da esfera religiosa, desde gerais da companhia até cardeais e papas; da esfera literária laica, desde Camilo Castelo Branco a José Saramago; como ainda da área política recente, sendo de salientar, em Portugal, Almeida Santos, ou os Presidentes da República José Sarney e Jorge Sampaio.

Sobre as muito problematizadas contradições de Vieira, veja-se MOREIRA José. As contradições do Padre António Vieira e outros escritos. Rio de Janeiro: Alba, 1943. 140 p.; RODRIGUES, Francisco. O P. António Vieira. Contradições e aplausos à luz de documentação inédita. In Revista de História, Vol. XI, 1922, p. 81-115. Para uma análise da complexa receção de Vieira, veja-se FRANCO, José Eduardo; REIS, Bruno Cardoso. Vieira na literatura anti-jesuítica. Lisboa: Roma Editora e Fundação Maria Manuela e Vasco Albuquerque D’Orey, 1997. 176 p.. Sobre a problemática da receção literária, veja-se HARDWICK, Lorna. Reception studies. Oxford: Classical Association by Oxford University Press, 2003. 136 p.

14 Oliveira Martins, História da civilização ibérica, Lisboa, Guimarães Editors, 2007, p. 326 
XVII, de João Manuel Pereira da Silva (1866), e Boca do Inferno, de Ana Miranda (1989). ${ }^{15}$ Com efeito, estes textos, através da forma como a personagem de António Vieira é caracterizada e colocada em cena, apresentam-nos interessantes chaves de leitura da vida e do significado da ação e do pensamento vieirianos, na relação com os projetos sociais, de Estado e de Igreja do seu tempo. Além disso, dão-nos conta de um dos modos como Vieira se torna personagem romanesca e dos aspetos e episódios da sua vida tomados como "materiais" no processo de criação literária.

Em nosso entender, "Mariana Pinta" e Boca do Inferno ilustram o já mencionado caráter paradoxal da perceção de António Vieira, nomeadamente ao realçarem, por um lado, feitos e pensamentos distintos que encerram elogios consideráveis e, por outro, comportamentos e ideias incómodos, geradores de uma intensa aversão e de uma feroz oposição ao jesuíta.

No respeitante às origens da contestação e da inimizade, no conto de Firmino da Silva, destaca-se, sobretudo, a defesa da causa dos índios; ${ }^{16}$ e no texto de Ana Miranda, por sua vez, salienta-se a defesa dos judeus, ${ }^{17}$ que faz de Vieira, como se lê, "o homem mais odiado de Portugal"18 e, no entender da personagem António de Souza de Menezes, também desgraçado e condenado em território internacional. ${ }^{19}$ Neste âmbito, é curioso notar, ainda em Boca do Inferno, o facto de António Vieira ter plena consciência do sentimento agónico que desperta, sobretudo no seu país, o que é comprovado pela recordação do seguinte episódio: "No ano passado houve uma arruaça

15 Consultem-se, a propósito, os seguintes textos: MARQUES, Wilton. Padre Vieira e os filhos de Tupá (Um conto esquecido de Firmino Rodrigues da Silva). In Navegações. Revista de Cultura e Literaturas de Língua Portuguesa, v. 10, n. 1 (2017), p. 79-83; MORAIS, Eunice de. Ficção e História no romance 'Boca do Inferno', Dissertação de Mestrado. Curitiba: Universidade Federal do Paraná, 2003.

16 Leia-se: "Tanto entusiasmo, tão fervorosa devoção pela causa dos Índios não podia deixar de acusarlhe inumerosos inimigos no meio de uma sociedade gangrenada pela corrupção e avidez de ganho. Seus compatriotas opuseram-se com toda a energia a causa dos desvalidos". Este excerto, bem como os que viermos a transcrever, é retirado da versão do conto de Firmino da Silva integrada no apêndice do ensaio "Padre Vieira e os filhos de Tupá (Um conto esquecido de Firmino Rodrigues da Silva)", da autoria de Wilton Marques, publicado em Navegações. Revista de Cultura e Literaturas de Língua Portuguesa, v. 10, n. 1 (2017), p. 79-83.

17 MIRANDA, Ana. Boca do Inferno. São Paulo: Companhia das Letras, 1989. 351 p., p. 184. Usamos aqui a versão $\quad$ online, $\quad$ disponível http://www.afag.com.br/professorrubens/artigos\%20e\%20outros/Boca+do+Inferno.pdf

18 Ibid., p. 184.

19 Ibid., p. 54. 
em Coimbra, onde um grupo de estudantes e gente baixa simulou um auto-de-fé queimando a minha figura. O que mais podem fazer contra mim? Queimar-me vivo?"20

Efetivamente, não podemos esquecer que António Vieira é um homem de ação e de uma reflexão arguta sobre os mais diversos temas (desde o destino de Portugal, passando pela crítica social, até à idealização utópica de um fim da história feliz, consubstanciado na sua visão do Quinto Império), destacando-se pelas propostas reformistas que apresenta. Além disso, afronta questões complexas, designadamente enquanto pregador, sempre com o sentido do dever de denunciar o mal, o pecado e a corrupção, bem como de indicar caminhos de conversão. Na obra de Ana Miranda, esta sua faceta denunciadora é referida diversas vezes. Transcrevemos, a título ilustrativo, uma delas:

O mundo está cheio de ladrões. E aqui [no Brasil] a coisa parece pior. Não que as pessoas daqui sejam diferentes, piores do que as outras. $\mathrm{O}$ homem é o mesmo em qualquer lugar. Aqui, todavia, não há vergonha de se cometer um ato delituoso, não há remordimento de consciência. (...) Perde-se o Brasil nas unhas escorregadias dos governantes. O povo daqui sofre por ser uma ralé ignorante do primeiro ao último. Os pobres cabritos de Deus, esses vão para o céu. ${ }^{21}$

Do mesmo modo, os poderosos sermões vierianos, nos quais o pregador sobressai como senhor da palavra, da beleza do verbo falado e escrito, que maneja como ninguém, suscitam antagonismos e, inclusivamente, rejeições violentas, como o demonstram as afirmações da personagem Gregório de Matos, manifestada a respeito de um livro de sermões do jesuíta: "Vieira era ao mesmo tempo o que todos esperavam que ele fosse e o que todos odiavam que fosse. Tudo que dizia ou escrevia tomava logo uma dimensão maior". ${ }^{22}$

Neste contexto, importa referir que, no romance de Ana Miranda, o governador-geral do Brasil, António de Souza Menezes (apelidado de "Braço de Prata") surge como o rosto maior da hostilidade relativamente a António Vieira, traçando uma imagem marcadamente negativa do jesuíta, em linhas fortemente hostis. Leia-se, a propósito, a seguinte passagem da obra:

\footnotetext{
20 Ibid., p. 196.

21 MIRANDA, Ana. Boca do Inferno. São Paulo: Companhia das Letras, 1989. 351 p., p. 96.

22 Ibid., p. 84.
} 
Quase sempre sonhava [António de Souza Menezes] com Vieira. Ele pensava no velho jesuíta com mais frequência do que podia admitir para si mesmo. Sonhara que se encontrava com Vieira ao lado do guindaste. [...]. Os dois duelavam. Antônio de Souza o derrotava. Via o corpo alquebrado do padre estendido, inerte, e tentava enfiar-lhe a espada no coração. Não via suas próprias mãos. Antônio de Souza dizia: - Por que não consigo matar-te? Acaso roubaste minhas mãos? Eram assim seus sonhos. Algo que não conseguia fazer. A culpa sempre ficava com Antônio Vieira. ${ }^{23}$

Mais à frente, António de Souza, em diálogo com o arcebispo João da Madre de Deus, reconhece o seguinte: “É como se visse padre Vieira. Ele aparece com seus cabelos brancos e desgrenhados e ri de mim. Eu o odeio". ${ }^{24}$

Cumpre-nos abrir aqui um parêntesis para notar que o desprezo do governadorgeral por este jesuíta em particular se estende à Companhia de Jesus e aos jesuítas em geral, ${ }^{25}$ o que remete para uma feição do antivieirismo a que atrás aludimos. Apesar de, neste caso, os exemplos poderem multiplicar-se, atentemos no excerto agora transcrito:

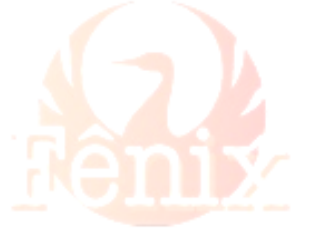

E noutro passo:
Padre Vieira sempre fora conhecido em Portugal como um homem rendido ao poder econômico. Por isso protegia os judeus, que representavam a riqueza. Lutava contra a escravidão dos indígenas, mas não esconderia isso algum interesse dos famélicos jesuítas? Talvez fosse um problema de consciência ou um impulso tirânico de catequese, uma vez que as normas inacianas eram fundamentais no ensino da doutrina. ${ }^{26}$

E estavam [os jesuítas] ali no Brasil defendendo a liberdade dos indígenas para os terem, eles mesmos, como cativos - de suas idéias. Como se podia explicar que sendo contra a escravidão calavam-se frente ao que ocorria com os negros africanos? Simples! O braço do negro era imprescindível ao enriquecimento da colônia. Assim eram os jesuítas e padre Vieira mais do que todos (...). ${ }^{27}$

\footnotetext{
23 Ibid., p. 103.

24 MIRANDA, Ana. Boca do Inferno. São Paulo: Companhia das Letras, 1989. 351 p., p. 103.

25 Ibid., p. 78.

26 Ibid., p. 78.

27 Ibid., p. 79.
} 
Voltando um pouco atrás, mais concretamente aos sentimentos de rancor e de antipatia de António de Menezes por Vieira, vejamos como são justificados no final do texto:

\begin{abstract}
ANTONIO DE SOUZA DE MENEZES (...) jamais esqueceu seu ódio por Vieira. Viveu o resto de seus dias atormentado pelo rancor e pelo arrependimento de seu pecado cometido nos anos que passou recolhido na quinta de Olivais. Vieira foi o único homem a saber que perversão fora essa, porém nunca a revelou. Ouvira-a em Lisboa, quando o Braço de Prata, então nomeado governador de Campo Maior, o procurara para que intercedesse a favor de um marujo preso pelo assassinato de uma marquesa. ${ }^{28}$
\end{abstract}

É, pois, a repulsa desmesurada e infundada, bem como o desejo de vingança, que motivam e instigam o Braço de Prata. Daí que o assassinato de Francisco Teles de Menezes, alcaide-mor da cidade da Bahia, resultante da rivalidade entre a fação dos Menezes e a dos Ravasco, sirva de pretexto para uma manifesta perseguição do governador-geral à família Ravasco, mas, sobretudo, a António Vieira, a quem atribui a responsabilidade do crime. Vieira sabe-se o alvo de António de Menezes, como o comprovam as suas afirmações: "O que o Braço de Prata quer é a mim. Sou eu quem o ameaça". ${ }^{29}$

Apesar de consciente desta perseguição e da tentativa para o derrotar, e de se sentir incapaz, como expressa, de "convencer a um governador colonial de meio braço sobre a inutilidade de seu ódio", António Vieira diz: “Já que a guerra começou, travarei mais uma batalha". ${ }^{30} \mathrm{Na}$ verdade, o amor pela família faz o padre jesuíta enfrentar o cansaço que sente e empenhar-se afincadamente na sua proteção e defesa, adotando, para isso, uma "posição conciliadora" e pacificadora. ${ }^{31}$ Esta atitude denota, realçandoos, o caráter humano, protetor e tolerante de Vieira, bem como a sua argúcia e inteligência, em nome da luta "pelas suas idéias de justiça e verdade". 32

Este modo de ser e de agir é igualmente posto em evidência em Manuel de Moraes - Crónica do Século XVII, nomeadamente pela referência ao envolvimento e ao

\footnotetext{
28 Ibid., p. 346-347.

29 MIRANDA, Ana. Boca do Inferno. São Paulo: Companhia das Letras, 1989. 351 p., p. 151.

30 Ibid., p. 152.

31 Ibid., p. 19.

32 Ibid., p. 341.
} 
empenho de António Vieira (na época, emissário e agente diplomático português em Haia) no processo de reconversão do protagonista Manuel de Moraes à religião católica e no consequente regresso à ordem religiosa inaciana (depois de este jesuíta ter abandonado a Companhia de Jesus e de, por amor, se ter convertido ao protestantismo). Para isso, Vieira dedica-se à delineação de uma estratégia: além de aconselhar Manuel de Moraes a escrever uma História da América Portuguesa, prepara, ele próprio, cartas de recomendação destinadas ao "provincial dos Jesuítas em Portugal, [a] alguns funcionários importantes e fidalgos distintos em Lisboa, e particularmente [a] Dom Francisco Manuel de Mello", ${ }^{33}$ missivas para o protagonista entregar aquando da sua chegada a Lisboa, tendo em vista a sensibilização dos destinatários e a consequente admissão de Moraes na Companhia, bem como a obtenção do perdão real. Ainda que os objetivos não tenham sido alcançados, este episódio evidencia a perspicácia, a sensibilidade e a dedicação de Vieira - designadamente por ter compreendido a sinceridade do arrependimento e o desejo de reconversão de Manuel de Moraes, tendo decidido auxiliá-lo -, assim como a sua agudeza de espírito e capacidade estratégica. Denotando, uma vez mais, a entrega e devoção plenas, o verdadeiro amor ao próximo.

Esta é apenas uma de entre as várias facetas de António Vieira sobrelevadas nas obras em análise, o que denota uma característica transversal aos três textos: o louvor e a exaltação da personalidade, da vida e da iniciativa do jesuíta. Glorifica-se a coragem, ousadia, o homem de causa, o defensor dos índios e dos mais fracos, o génio do escritor e do orador e a argúcia de pensamento. Enfim, a sua ação política, diplomática e religiosa. Na verdade, este lado vieiriano acaba por ser mais apetecível, constituindo-se como topica recorrente nas criações literárias em que Vieira entra como personagem, nomeadamente na literatura brasileira e, mais concretamente, nos textos em análise.

Em Manuel de Moraes - Crónica do Século XVII, o elogio é muito claro e obviamente sublinhado. Vieira é descrito como um "Jesuíta celebrizado, pregador excelso", ${ }^{34}$ um "missionário magistral", 35 um "verdadeiro revolucionário político e religioso", ${ }^{36}$ Uma

\footnotetext{
33 SILVA, J. M. Pereira da. Manuel de Moraes. Crónica do Século XVII. Rio de Janeiro: Garnier, 1866, 108 p., p. 86. Usamos aqui a versão online, disponível em http://www.gutenberg.org/ebooks/29819.

34 Ibid., p. 75.
} 
Alma grande, sublime espírito, eloquência superior, corpo afeito a trabalhos e fatigas, indiferente a perigos (...) um dos homens mais extraordinários que tem o mundo produzido [... que] legou à posterioridade um nome de engenho seleto, grandioso e admirável. ${ }^{37}$

Note-se que a excecionalidade de Vieira aparece enfatizada através da menção à sua extrema dedicação e entrega à defesa, educação e evangelização dos índios, característica igualmente referida em Boca do Inferno, e amplamente retratada no texto "Mariana Pinta", no qual, aliás, é temática central. Atentemos, a propósito, no excerto do conto:

Sem contemplações a interesses humanos, como superior que era a todos eles, o missionário por toda parte expande enérgico os sentimentos de seu coração: ora convoca os principais do país para advogar a causa dos indígenas, ora embrenha-se pelas florestas a dentro, regenerando as almas na água misteriosa do batismo, anunciando aos gentios uma religião pura, cheia de bondade e de esperança. ${ }^{38}$

Por sua vez, no romance de Ana Miranda, Vieira relembra a sua estada no Maranhão. Diz ele: "Era preciso converter os gentios do Maranhão. Fazer com que (...) acreditassem em Deus os índios naturais da terra". ${ }^{39}$ E lê-se ainda que Vieira "Lutara para cerrar os sertões e proibir que não houvesse resgates, e para que fossem declarados livres todos os resgatados". 40

Neste contexto, cumpre-nos notar o facto de o texto de Firmino Rodrigues da Silva salientar o desagrado desencadeado pela luta de Vieira contra a escravização dos indígenas, mais concretamente por pôr em causa os interesses e as pretensões dos colonos do Maranhão, o que desencadeia a prisão do jesuíta e a sua deportação para a capital portuguesa.

\footnotetext{
35 Ibid., p. 78.

36 Ibid., p. 81.

37 Ibid., p. 82.

38 MARQUES, Wilton. Padre Vieira e os filhos de Tupá (Um conto esquecido de Firmino Rodrigues da Silva). In:__ Navegações. Revista de Cultura e Literaturas de Língua Portuguesa, v. 10, n. 1 (2017), p. 82.

39 MIRANDA, Ana. Boca do Inferno. São Paulo: Companhia das Letras, 1989. 351 p., p. 44-45.

40 Ibid., p. 45.
} 


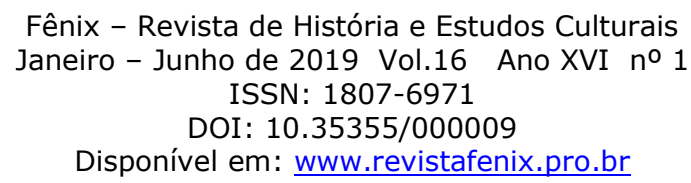

Convém abrirmos aqui um parêntesis para lembrarmos o célebre caso do sermão de Santo António aos Peixes, precisamente pelo descontentamento provocado pela denúncia das práticas esclavagistas dos colonos maranhenses. De facto, como bem sabemos, a temática dos índios é central na obra vieiriana. As linhas que Vieira dedica ao tema permitem-nos perceber a sua genialidade na utilização da palavra, extensível, aliás, ao tratamento de qualquer assunto, não só através da escrita, mas também do discurso oral. Um talento sublinhado nos romances de Pereira da Silva e de Ana Miranda. Daquele, podemos ler um trecho bastante significativo:

(...) empregava a pena escrevendo constantemente e publicando umas sobre outras obras primorosas, e não poupava a palavra, falando dos púlpitos aos reis, aos nobres, ao clero, e ao povo, que se apinhavam nos templos para ouvi-lo pregar, e admirar-lhe a portentosa eloquência, e a instrução variada e interessante. (...). Conseguira fazer ressoar os templos da Bahia, de Lisboa e de Roma sob os ecos agradáveis e harmoniosos de sua voz admirável, e gemer os prelos tipográficos com a tarefa interrompida de manufacturar os seus livros. (...) Despedia a sua palavra o fogo sagrado. Queimava como incêndio, feria como punhal afiado e agudo. Seduzia, arrastava, cativava, e enchia ao mesmo tempo de encantos os ouvintes todos. Manifestava a sua pena uma lógica cerrada, um estilo pomposo e correto, uma cópia espantosa de erudição, e imagens apropriadas, interessantes e arrebatadoras. ${ }^{41}$

Já em Boca do Inferno, além dos elogios de Gregório de Matos, destaca-se o seguinte episódio contado pelo judeu Samuel da Fonseca:

Então estou diante do ilustre jesuíta de quem tanto fala meu amigo - e vosso irmão - Bernardo Ravasco. (...). Nosso povo só tem a vos agradecer. (...) há muito anos, estive convosco, em Rouen, quando lá fostes vos encontrar com judeus portugueses fugidos à Inquisição (...). (...) Em Amsterdão, continuou o rabino, - tive o prazer de assistir à prédica do afamado Manasseh ben Israel, à qual, com muita cordialidade, fostes também ouvir. Sabendo do ouvinte que tinha na assembleia, Manasseh procurou exibir seus dotes de orador e tentou provar a superioridade da antiga lei. Soube que vós procurastes o hakham Manasseh à saída e que se deu uma disputa retórica que durou longo tempo e à qual, infelizmente, fui privado de assistir. Dois mestres de teologia, dois sábios. Ambos possuíam igual força de argumentação, igual amor pela disputa de idéias, ambos versados na

41 SILVA, J. M. Pereira da. Manuel de Moraes. Crónica do Século XVII. Rio de Janeiro: Garnier, 1866, 108 p., p. 81. 


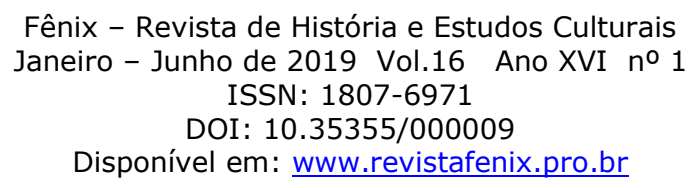

Escritura e, vencidos pelo cansaço, saíram sem um poder convencer ao outro. ${ }^{42}$

De facto, a palavra vieiriana, pregada e escrita, atrai multidões para ouvir o jesuíta, e ainda hoje, colhe o interesse de muitos que continuam a lê-lo com grande proveito literário e vivencial. ${ }^{43}$ Saramago, que lhe devotava confessada admiração, chegou a declarar que a língua portuguesa atingiu uma bela incomparável na fala e na escrita deste jesuíta. O Padre António Vieira é, incontornavelmente, uma das figuras maiores da literatura portuguesa e brasileira, e a mais "imperial" na sua exímia tessitura de uma prosa complexa do barroco, tornando-se esse estatuto mais inequívoco com a extrema valorização de Fernando Pessoa na Mensagem, onde o denomina "Imperador da Língua Portuguesa", e no Livro do Desassossego, onde o torna seu mestre da língua, a sua pátria literária.

A propósito, recuperemos ainda uma passagem significativa do discurso de homenagem de Jorge Sampaio, então Presidente da República Portuguesa, a António Vieira, proferido em 1997, aquando da comemoração do tricentenário da morte do pregador:

Em Vieira, no princípio, era o verbo e, no fim, será ainda o verbo. Ele habitará sempre esse povo de palavras com as quais confundiu a vida e fez a obra. É nelas - e não na ordem do político, como alguns pensam - que as suas palavras se cumprem. Esse império discursivo, essa catedral verbal, esse teatro de eloquência, esse prodígio de 'engenharia sintática', essa 'grande certeza sinfónica', como disse Fernando Pessoa/Bernardo Soares, permanecerá como um monumento de palavras que desafiará o tempo e a passagens dos homens. ${ }^{44}$

Em conclusão: é esta grandeza de Vieira que explica o fascínio sentido pela sua figura e o tom de louvor entusiástico com que é apresentada, fazendo-a sobressair como personagem nas obras analisadas. A mesma grandeza que faz de Vieira personagem recorrente e heroica na história e em várias manifestações artísticas: na literatura, na

42 MIRANDA, Ana. Boca do Inferno. São Paulo: Companhia das Letras, 1989. 351 p., p. 176-177.

43 Cf. FRANCO, José Eduardo. O império da escrita: A escrita como poder na Companhia de Jesus: o Caso da Obra Vária do Padre António Vieira. In BASTOS, Neusa Barbosa (Org.). Língua Portuguesa: história, memória e intersecções lusófonas. São Paulo: EDUC-IP-PUC-SP, 2018, p. 31-57.

44 Atas da reunião plenária de 18 de julho de 1997, "Sessão solene evocativa dos 300 anos da morte do Padre António Vieira”. In Diário da Assembleia da República, 2. ' Sessão Legislativa, 19 de julho de 1997, p. 3555. 

ISSN: $1807-6971$

DOI: $10.35355 / 000009$

Disponível em: www.revistafenix.pro.br

pintura, na música, no cinema. Uma figura cativante e enaltecida ou, pelo menos, referida, frequente na memória recebida e construída. 